\title{
В.А. ГАНДЗЮК
}

\section{СТАН НОРМАТИВНО-ПРАВОВОГО РЕГУЛЮВАННЯ УПРАВЛІННЯ ПРОФІЛАКТИКОЮ НЕІНФЕКЦІЙНИХ ЗАХВОРЮВАНЬ}

\author{
Державна наукова установа «Науково-практичний центр профрілактичної і клінічної медицини» \\ Державного управління справами, м. Київ, Україна
}

\begin{abstract}
Мета: визначити напрямки удосконалення нормативно-правового забезпечення заходів профілактики неінфекційних захворювань у дорослого населення в умовах багатопрофрільного закладу охорони здоров'я на основі узагальнення та аналізу діючих у системі охорони здоров'я України правових актів.

Матеріали і методи. Розглянуто офріційні нормативні документи щодо управління профрілактикою неінфрекційних захворювань. При проведенні їх аналізу використано контент-аналіз, системний підхід і аналіз, бібліограсрічний та історичний методи.

Результати. Покращення профрілактичних заходів серед населення, виходячи із загальної десрініції «диспансеризація», передбачає розробку та впровадження періодичних профрілактичних оглядів серед дорослого населення за принципом їх проведення у цільових групах, методологічним базисом для яких мають стати скринінгові програми з раннього виявлення найпоширеніших неінфекційних захворювань.

Висновки. При проведенні контент-аналізу нормативно-правової бази щодо управління профілактикою в Україні встановлено, що серед чинних наказів МОЗ України відсутні чіткі критерії, що відображають ступінь дотримання організаційних принципів надання профрілактичної допомоги, як наслідок цього оцінка якості профілактичної допомоги та її ефективності не проводиться, а сучасні управлінські технології не використовуються.
\end{abstract}

КЛЮЧОВІ СЛОВА: диспансеризація; профілактичні огляди; скринінгові програми; управління профілактикою; неінфекційні захворювання.

Одним із важливих етапів подолання епідемії неінфекційних захворювань (НІ3) є розробка Глобального плану дій ВООЗ з профрілактики неінфекційних захворювань та боротьби з ними на 2013-2020 рр. Документ включає дев'ять добровільних глобальних цілей і глобальну систему моніторингу, які були прийняті ВООЗ ще у 2013 р. [1-3].

Дев'ять добровільних глобальних цілей щодо неінфекційної патології спрямовані на скорочення шкідливого вживання алкоголю, поширеності недостатньої фрізичної активності, споживання солі, вживання тютюну та поширеності підвищеного кров'яного тиску, а також на припинення зростання числа випадків цукрового діабету та ожиріння, розширення охоплення зусиль для профілактики інфарктів та інсультів, забезпечення доступу до основних технологій та лікарських засобів [4]. Вибір саме таких цілей зумовлено провідною роллю перелічених чинників ризику в фрормуванні сучасних масштабів епідемії неінфекційних захворювань [4].

Україна у відповідь на епідемію неінфекційних захворювань розробила проект Національного плану дій щодо неінфекційних захворювань, в основу якого покладено пріоритетні напрямки державної політики у сорері охорони здоров'я, комплексний підхід, оснований на наукових доказах, інтегруванні досягнень соціальних і пове-

(c) В.А. Гандзюк, 2017 дінкових наук, стратегічний соціальний маркетинг [17, 19-20].

Успішна реалізація сучасних стратегічних завдань у сорері охорони здоров'я безпосередньо пов'язана зі зміщенням акцентів із лікувальної роботи на профрілактичну, створенням умов для збереження та зміцнення здоров'я, утвердженням здорового способу життя, фрормуванням відповідального ставлення до особистого здоров'я.

Виникла необхідність змінити підходи до вирішення проблем здоров'я. Крім клінічної спрямованості медицини і класичної профрілактики (запобігання окремим захворюванням, своєчасна їх діагностика, профрілактика ускладнень, рецидивів, інвалідності тощо) на порядку денному стоїть необхідність сконцентрувати головну увагу на активній профрілактиці (підтримка первинного рівня і зміцнення здоров'я на основі коригування способу життя і оздоровчих заходів, управління здоров'ям та його конструюванням).

Важливе місце для розвитку профрілактики посідають проблеми законодавчого забезпечення модернізації системи надання профрілактичної допомоги. Незважаючи на великий масив законодавчих актів як державного, так і регіонального рівнів, стан профрілактичної допомоги не можна назвати благополучним. Слід підкреслити, що не всі прийняті закони забезпечують необхідну правову 
підтримку ефективному розвитку профрілактики. Із ряду питань у цій галузі закони відсутні або перебувають у стадії розробки. Тому на сучасному етапі назріла необхідність розробки нових законів, а також внесення суттєвих доповнень і змін до чинного медичного законодавства і проведення активної нормотворчої роботи у цій ссрері.

Мета дослідження: визначити напрямки удосконалення нормативно-правового забезпечення заходів профрілактики неінфекційних захворювань у дорослого населення в умовах відомчого закладу охорони здоров'я на основі узагальнення та аналізу діючих у системі охорони здоров'я України правових актів.

Матеріали і методи. Розглянуто офріційні нормативні документи щодо управління профрілактикою неінфекційних захворювань. При проведенні їх аналізу використано контент-аналіз, системний підхід і аналіз, бібліографрічний та історичний методи.

Об'єктом дослідження були матеріали роботи ВОО3, нормативно-правові акти України (Конституція України, Закон України «Основи законодавства України про охорону здоров'я», Постанови КМУ, накази МОЗ України, Головного управління державної служби України, Державного управління справами), що регулюють діяльність 3 профрілактики НІ3 у дорослого населення.

Система нормативно-правового забезпечення профрілактики захворювань являє собою сукупність законів і підзаконних нормативних актів, які створюють нормативно-правове поле для фрункціонування системи профрілактики захворювань і виконання нею свого призначення. У широкому розумінні йдеться про Конституцію України (стаття 49) [5], Закон України «Основи законодавства України про охорону здоров'я», закони України, укази та розпорядження Президента України, постанови та розпорядження Кабінету Міністрів України, які визначають компетенцію суб'єктів системи забезпечення профрілактики захворювань, а також відомчі нормативні акти у фрормі наказів, директив, положень, статутів, правил, інструкцій тощо.

Результати дослідження та їх обговорення. На сьогодні заходи 3 профрілактики захворювань у країні регламентовано багатьма нормативноправовими документами. Фундаментом правової системи в Україні є Конституція, яка, як Закон прямої дії, визначає підходи до фрормування політики в усіх сорерах діяльності, у т. ч. і в охороні здоров'я, визнаючи право кожного на охорону здоров'я, медичну допомогу та медичне страхування. У Конституції України міститься низка статей, що стосуються питань охорони здоров'я. Так, ст. 49 констатує, що кожен має «право на охорону здоров'я, медичну допомогу та медичне страхування». Конституція зазначає, що «охорона здоров'я забезпечується державним фрінансуванням відповідних соціально-економічних, медико-санітарних і оздоровчо-профрілактичних програм». Основний закон не уточнює зміст цих програм, але в ньому відчувається намагання гарантувати реалізацію цього права: «Держава створює умови для ефективного і доступного для всіх громадян медичного обслуговування. У державних і комунальних закладах охорони здоров'я медична допомога надається безоплатно; існуюча мережа таких закладів не може бути скорочена. Держава сприяє розвиткові лікувальних закладів усіх форм власності». Сорормульоване у такий спосіб право радше визначає організаційні аспекти охорони здоров'я, аніж гарантує належний рівень життя і медичного обслуговування. Ця ж стаття містить положення, які свідчать про профрілактичну спрямованість охорони здоров'я, оскільки зазначає, що «держава дбає про розвиток фрізичної культури і спорту, забезпечує санітарно-епідемічне благополуччя».

У Законі України «Основи законодавства України про охорону здоров'я» від 19.11.1992 р. № 2802-XII (чинна редакція зі змінами та доповненнями від 06.11.2017 р.), міститься низка статей, що прямо або опосередковано стосуються заходів із профрілактики захворювань, але загалом там висвітлені виключно організаційні аспекти профрілактики усіх класів захворювань (від травматизму до епідемій інфекційних хвороб) [6]

Зокрема, у статті 4 «Основні принципи охорони здоров'я», наголошується на тому, що один із принципів підходу до охорони здоров'я має «попереджувально-профрілактичний характер».

Основами законодавства України про охорону здоров'я регламентовано проведення обов'язкових медичних оглядів населення (стаття 31 «Обов'язкові медичні огляди») та роботи з фрормування здорового способу життя (стаття 32 «Сприяння здоровому способу життя населення»).

Так, стаття 31 «Обов'язкові медичні огляди» закріплює положення про те, що «з метою охорони здоров'я населення організовуються профілактичні медичні огляди неповнолітніх, вагітних жінок, працівників підприємств, установ і організацій з шкідливими і небезпечними умовами праці, військовослужбовців та осіб, професійна чи інша діяльність яких пов'язана 3 обслуговуванням населення або підвищеною небезпекою для оточуючих.

Власники та керівники підприємств, установ і організацій несуть відповідальність за своєчасність проходження своїми працівниками обов'язкових медичних оглядів та за шкідливі наслідки для здоров'я населення, спричинені допуском до роботи осіб, які не пройшли обов'язкового медичного огляду. Перелік категорій населення, які повинні проходити обов'язкові медичні огляди, періодичність, джерела фрінансування та порядок цих оглядів визначаються Кабінетом Міністрів України». 
Стаття 32 «Сприяння здоровому способу життя населення» регламентує, що «держава сприяє утвердженню здорового способу життя населення шляхом поширення наукових знань 3 питань охорони здоров'я, організації медичного, екологічного і фрізичного виховання, здійснення заходів, спрямованих на підвищення гігієнічної культури населення, створення необхідних умов, в тому числі медичного контролю, для заняття фрізкультурою, спортом і туризмом, розвиток мережі лікарськофрізкультурних закладів, профрілакторіїв, баз відпочинку та інших оздоровчих закладів, на боротьбу із шкідливими для здоров'я людини звичками, встановлення системи соціально-економічного стимулювання осіб, які ведуть здоровий спосіб життя».

Питання профрілактики висвітлені за рівнями надання медичної допомоги у статті 35.1: «первинна медична допомога - медична допомога, що надається в амбулаторних умовах або за місцем проживання (перебування) пацієнта лікарем загальної практики - сімейним лікарем і передбачає надання консультації, проведення діагностики та лікування найбільш поширених хвороб, травм, отруєнь, патологічних, фрізіологічних (під час вагітності) станів, здійснення профрілактичних заходів...» та у статті 35.2, відповідно, «вторинна (спеціалізована) медична допомога - медична допомога, що надається в амбулаторних або стаціонарних умовах лікарями відповідної спеціалізації (крім лікарів загальної практики - сімейних лікарів) у плановому порядку або в екстрених випадках і передбачає надання консультації, проведення діагностики, лікування, реабілітації та профрілактики хвороб».

Провідною частиною профрілактичного напрямку охорони здоров'я і методом активного динамічного спостереження за станом здоров'я усіх груп населення є диспансеризація населення [18]. Основна мета диспансеризації полягає в збереженні й зміцненні здоров'я населення, збільшенні тривалості життя і підвищенні продуктивності праці шляхом активного виявлення та лікування початкових форм захворювань, вивчення й усунення фракторів, які зумовлюють виникнення й поширення захворювань, а також проведення комплексу соціальних, санітарно-гігієнічних, профрілактичних, лікувально-оздоровчих та організаційних заходів.

Наказ МОЗ України від 17.08.2010 р. № 728 «Про порядок диспансеризації населення» певною мірою врегулював порядок здійснення диспансеризації, проте окремі положення цього нормативного документа створили «хаос» у трактуванні понять «диспансерний нагляд» та «профрілактичний медичний огляд» [12].

Диспансеризація - це метод медичного обслуговування населення, який передбачає активне виявлення захворювань на ранніх стадіях, нагляд за певними групами хворих із метою забезпечення їх життєдіяльності та працездатності, проведення оздоровчих заходів, обов'язкові медичні огляди деяких категорій населення тощо. Диспансеризація проводиться закладами охорони здоров'я державної та комунальної форм власності. У диспансеризації беруть участь вищі медичні навчальні заклади усіх рівнів акредитації, заклади післядипломної освіти, наукові установи державної та комунальної фрорм власності [13-15].

Порядок проведення медичних оглядів працівників окремих категорій розроблений на виконання ст. 17 Закону України «Про охорону праці». Він же і визначає процедуру проведення попереднього (під час прийняття на роботу) та періодичних (протягом трудової діяльності) медоглядів робітників, зайнятих на важких роботах та роботах із шкідливими чи небезпечними умовами праці або таких, де є потреба у професійному виборі, щорічному обов'язковому медичному огляді осіб віком до 21 року.

Попередній медичний огляд проводять під час прийняття на роботу 3 метою: визначення стану здоров'я працівника і реєстрації необхідних об'єктивних показників здоров'я та можливості виконання без погіршення стану здоров'я професійних обов'язків в умовах дії конкретних шкідливих та небезпечних факторів виробничого середовищаітрудового процесу; виявлення професійних захворювань, що виникли раніше при роботі на попередніх виробництвах та попередження виробничозумовлених і профресійних захворювань (отруєнь).

Періодичні медичні огляди проводять з метою: своєчасного виявлення ранніх ознак гострих і хронічних професійних захворювань (отруєнь), загальних та виробничозумовлених захворювань; забезпечення динамічного спостереження за станом здоров'я працівників в умовах дії шкідливих та небезпечних фракторів і трудового процесу; вирішення питання щодо можливості працівника продовжувати роботу в умовах дії конкретних шкідливих та небезпечних виробничих фракторів і трудового процесу; розробки індивідуальних та групових лікувально-профрілактичних та реабілітаційних заходів працівникам, які віднесені за результатами медичного огляду до групи ризику; проведення відповідних оздоровчих заходів [7, 10].

Відповідальність за проведення диспансеризації та медичних оглядів насамперед покладають на дільничного лікаря та громадянина України. Медичний огляд проводять лише за згодою громадян, отже, ця медична послуга не є обов'язковою. Громадяни України повинні бути зацікавлені у проходженні диспансеризації, у тому числі знайти час для її проходження.

Мінімально необхідний (обов'язковий) обсяг обстежень при диспансеризації населення регламентований наказом МО3 України від 27.08.2010 р. за № 728 «Про диспансеризацію 
населення». Адміністративні території та заклади охорони здоров'я, які мають достатні матеріальнотехнічні та кадрові ресурси, можуть проводити щорічні (періодичні) диспансерні огляди населення із залученням більш широкого кола спеціалістів та більшим обсягом лабораторних та інструментальних обстежень. Варто зазначити, що в наказі МО3 України від 27.08.2010 р. № 728 «Про диспансеризацію населення» не надано чітких вказівок щодо ведення облікових статистичних фрорм, саме щодо диспансерних хворих.

В Україні також існують галузеві нормативні документи, які визначають порядок проведення диспансеризації та періодичних медичних оглядів серед працівників певних категорій, що затверджені різними міністерствами та центральними органами виконавчої влади (Міністерство оборони України, Міністерство внутрішніх справ України, Міністерство України з питань надзвичайних ситуацій та у справах захисту населення від наслідків Чорнобильської катастрофи, Міністерство транспорту та зв'язку України, Адміністрація Державної прикордонної служби України, Служба безпеки України, Державний департамент 3 питань виконання покарань, Державний комітет ядерного регулювання України тощо). Проходження медичних оглядів такими працівниками є обов'язковим. Відповідальність за охоплення працівників медичними оглядами, своєчасність проходження профрілактичних оглядів несуть керівники підприємств, установ, закладів та підрозділів, роботодавці.

Спеціальній перевірці підлягають відомості щодо стану здоров'я особи, яка претендує на зайняття посади, пов'язаної з виконанням функцій держави або місцевого самоврядування, та зазначені у пункті 1 частини першої статті 4 3акону України «Про засади запобігання і протидії корупції» (крім кандидатів на пост Президента України, кандидатів у народні депутати України, кандидатів у депутати Верховної Ради Автономної Республіки Крим, місцевих рад та на посади сільських, селищних, міських голів) відповідно до наказу Міністерства охорони здоров'я України від 30.07.2012 р. № 578 (зареєстровано в Міністерстві юстиції України 21.08.2012 р. за № 1405/21717) «Порядок проведення спеціальної перевірки відомостей про стан здоров'я особи, яка претендує на зайняття посади, пов'язаної 3 виконанням функцій держави або місцевого самоврядування». Цей Порядок визначає організацію проведення медичного огляду особи, яка претендує на зайняття посади, пов'язаної з виконанням функцій держави або місцевого самоврядування. Медичний огляд особи проводять перед прийняттям на роботу (службу) з метою встановлення ії придатності за станом здоров'я до роботи (служби). Медичний огляд особи проводять в закладах охорони здоров'я всіх фрорм власності, що мають ліцензію на медичну практику, акредитовані в установленому законодавством порядку та внесені у реєстр закладів охорони здоров'я, які проводять медичні огляди осіб, що претендують на зайняття посади, пов'язаної з виконанням функцій держави або місцевого самоврядування, який ведеться Міністерством охорони здоров'я України [8-11].

Щорічний профрілактичний медичний огляд державних службовців регламентовано наказом Міністерства охорони здоров'я України, Головного управління державної служби України, Державного управління справами від 18.02.2003 р. № 75/24/1 (зареєстровано в Міністерстві юстиції України 06.03.2003 р. за № 184/7505) «Про проведення щорічного профрілактичного медичного огляду державних службовців».

Це Положення встановлює:

- єдиний порядок організації проведення щорічного профрілактичного медичного огляду державних службовців керівниками відповідних органів державної влади, де працює державний службовець;

- єдиний порядок проведення щорічного профрілактичного медичного огляду державних службовців лікувально-профрілактичними закладами за переліком, що визначається медичним управлінням Державного управління справами та керівниками структурних підрозділів із питань охорони здоров'я обласних, Київської міської державної адміністрації за погодженням з Головним управлінням організації медичної допомоги населенню Міністерства охорони здоров'я України. Медичний огляд проводять 3 метою визначення стану здоров'я державних службовців та проведення профрілактичних і лікувальних заходів.

Таким чином, загальна диспансеризація в Україні не є обов'язковою, проводиться за згодою громадян, на противагу цьому в Україні існують нормативні документи, які визначають порядок обов'язкового проведення диспансеризації (профрілактичних оглядів) серед працівників певних категорій, у т. ч. державних службовців, що зумовлено особливостями умов праці та вимогами, які пред'являються певним категоріям працівників і пов'язані з виконанням їх професійної діяльності.

Окремі питання щодо нормативно-правового регулювання процесу управління профрілактикою всього населення України, а не окремих категорій (організованого контингенту), потребують суттєвого перегляду, деталізації та змістового наповнення. Особливо гостро стоїть питання щодо чіткого розмежування понять «диспансеризація», «профрілактичний медичний огляд» та визначення порядку проведення профрілактичних медичних оглядів пацієнтів, котрі перебувають під диспансерним наглядом (наявність у пацієнта однієї хронічної патології не виключає можливість виникнення ще декількох).

Покращення профрілактичних заходів серед населення, виходячи із загальної десрініції «дис- 
пансеризація», передбачає розробку та впровадження обов'язкових періодичних профрілактичних оглядів серед дорослого населення за принципом їх проведення у цільових групах (статевовікових та ін.), методологічним базисом для яких мають стати скринінгові програми з раннього виявлення найпоширеніших неінфрекційних захворювань.

Отже, на нашу думку, основними шляхами вирішення нагальних проблемних питань щодо удосконалення управління профрілактикою неінфекційних захворювань, зокрема, щодо удосконалення нормативно-правового підґрунтя повинні стати:

1. У сорері підвищення доступності медичних послуг:

- чітке структурне розмежування з конкретизацією та визначенням питань проорілактики первинного, вторинного й третинного рівнів медичної допомоги; оптимізація системи медичної допомоги з акцентом на надання профрілактичної допомоги для задоволення медичних потреб населення, зокрема шляхом створення чіткої структурованої системи профрілактики;

- прийняття нормативно-правових актів щодо внесення змін до посадових інструкцій сімейних лікарів, медичних сестер, відділень профрілактики 3 зобов'язанням проведення конкретних профілактичних заходів, визначенням критеріїв оцінки виконання лікарем функцій з профрілактики та механізмів мотивації медпрацівників;

- визначення потреб у медичних кадрах для задоволення потреб населення у різних видах медичної допомоги; забезпечення підготовки медичних кадрів відповідно до потреб галузі; стандартизація навчання просрілактики як на перед-, так і на післядипломному рівні. Підготовка кадрів та поліпшення роботи з популяризації здорового способу життя;

- забезпечення адекватного ресурсного забезпечення профрілактичних заходів на всіх рівнях надання медичної допомоги;

- запровадження телемедичних технологій у діяльність системи медичного обслуговування;

- створення адекватної системи управлінської вертикалі реалізації профрілактичних заходів у сорері охорони здоров'я;

- розробка та реалізації програм щодо фрормування здорового способу життя, в тому числі програм зниження вживання алкоголю і тютюну, запобігання та боротьби 3 немедичним прийманням наркотичних і психотропних засобів;

- здійснення заходів щодо збереження здоров'я громадян упродовж їх життя.

2. У сорері підвищення якості профрілактичних заходів у системі охорони здоров'я:

- створення ефективної системи стандартизації профрілактичних медичних послуг, розробка та впровадження нормативно-правових актів щодо медичних стандартів надання медичної допомоги,
3 дотриманням принципу мультидисциплінарного складу робочих груп та фрормування окремого пулу рекомендацій щодо профрілактичних превенцій;

- створення передумов для впровадження оцінки медичних технологій 3 клінічної ефективності, економічної доцільності, організаційних проблем та проблем безпеки для пацієнтів у зв'язку з застосуванням певної профрілактичної технології;

- перехід до закупівлі державою послуг у закладів охорони здоров'я на контрактній основі (у закладів охорони здоров'я, що надають первинну медичну допомогу - оплата за кількість осіб, у закладів охорони здоров'я, що надають спеціалізовану (вторинну) і високоспеціалізовану (третинну) медичну допомогу - залежно від обсягів, структури і якості наданої медичної допомоги);

- покращення матеріально-технічного обладнання у закладах охорони здоров'я: проведення інвентаризації та розроблення примірних табелів матеріально-технічного оснащення закладів охорони здоров'я;

- наукове обґрунтування та розробка методології формування та впровадження системи індикаторів якості профрілактики;

- розробка та затвердження нормативно-правових актів (примірних положень) для відділень профрілактики;

- оновлення фрорм первинної медичної документації, виходячи з завдань, які повинна вирішувати система охорони здоров'я із профілактичних заходів;

- запровадження інноваційних технологій надання профрілактичної допомоги.

3. Створення економічної мотивації для підвищення якості медичного обслуговування:

- створення економічної мотивації для покращення якості профрілактичної допомоги, зокрема шляхом зміни оплати праці працівників галузі охорони здоров'я за рахунок виділення двох складових: постійної (на основі єдиної тарифної сітки), змінної - залежно від обсягу і якості профрілактичної допомоги.

\section{Висновки}

При проведенні контент-аналізу нормативноправової бази щодо управління профрілактикою в Україні встановлено, що серед чинних наказів MO3 України відсутні чіткі критерії, що відображають ступінь дотримання організаційних принципів надання профрілактичної допомоги, як наслідок цього оцінка якості профрілактичної допомоги та іiі ефрективності не проводиться, а сучасні управлінські технології (матеріальне стимулювання персоналу) не використовуються. На сьогодні надзвичайно важко застосовувати на практиці залежність між оплатою праці медичного персоналу та обсягом і якістю наданих профрілактичних послуг (закінчених періодичних профрілактичних медичних оглядів, охоплення прикріпленого населення 
диспансерним наглядом, виявлення потенційно небезпечних хронічних неінфекційних захворювань на ранніх стадіях тощо). Радше переважає парадигма хвороби - зацікавленість медичних працівників лікуванням гострої патології та загострень НІ3 переважає над прихильністю до профрілактичних програм.

Окрім цього, аргументовано необхідність обґрунтування та розробки методології розподілу коштів на профрілактичні послуги. Потребує до- опрацювання база науково обґрунтованих державних медичних стандартів профілактики неінфекційних захворювань.

Перспективи подальших досліджень полягають у тому, що, окрім удосконалення нормативної бази щодо управління профрілактикою НІ3, потребує стандартизації програми навчання профрілактики як на перед-, так і на післядипломному рівні, підготовка кадрів та поліпшення роботи з популяризації здорового способу життя.

\section{Список літератури}

1. Курс на оздоровление. Европейская стратегия профилактики и борьбы с неинсекционными заболеваниями, 2012-2016. - Копенгаген : ЕРБ ВОЗ, 2012. - 66 с.

2. План действий по реализации Европейской стратегии профилактики и борьбы с неинфекционными заболеваниями, 2012-2016 гг. - Копенгаген : ЕРБ ВОЗ, 2012. - 33 с.

3. Современные подходы к профилактике заболеваний в мире [Электронный ресурс]. - Режим доступа : http:// meduniver.com/Medical/profilaktika/12.html. - Название с екрана.

4. Европейская база данных «Здоровье для всех» [Электронный ресурс]. - Режим доступа : http://data.euro.who.int/ hfadb/shell_ru.htm.l. - Название с екрана.

5. Конституція України [Електронний ресурс]. - Режим доступу : http://zakon0.rada.gov.ua/laws/show/254\%D0\%BA/96\%D0\%B2\%D1\%80. - Назва з екрану.

6. Основи законодавства України про охорону здоров'я : Закон України [Електронний ресурс]. - Режим доступу : http://zakon2.rada.gov.ua/laws/show/2801-12. - Назва з екрану.

7. Про обов'язкові медичні огляди деяких категорій населення : постанова КМУ від 5 серпня 1994 року № 532 [Електронний ресурс]. - Режим доступу : http://zakon3.rada.gov.ua/laws/show/532-94-\%D0\%BF?info=1. - Haзва 3 екрану.

8. Про Національну стратегію з оздоровчої рухової активності в Україні на період до 2025 року : указ Президента України від 9 лютого 2016 року № 42/2016 «Рухова активність - здоровий спосіб життя - здорова нація» [Електронний ресурс]. - Режим доступу : http://www.president.gov.ua/documents/422016-19772 - Назва з екрану.

9. Про затвердження переліків закладів охорони здоров'я, лікарських, провізорських посад та посад молодших спеціалістів з фрармацевтичною освітою у закладах охорони здоров'я : наказ МОЗ України від 28.10.2002 р. № 385 [Електронний ресурс]. - Режим доступу : http://zakon3.rada.gov.ua/laws/show/z0892-02. - Назва з екрану.

10. Про проведення щорічного профілактичного медичного огляду державних службовців (зі змінами) : наказ МОз України, Головного управління державної служби України, Державного управління справами від 18.02.2003 р. № 75/24/1 (зареєстровано в Міністерстві юстиції України 6 березня 2003 р. за № 184/7505).

11. Про затвердження Порядку проведення медичних оглядів працівників певних категорій молодших спеціалістів 3 фрармацевтичною освітою у закладах охорони здоров'я : наказ МОЗ України від 21.05.2007 р. за № 246 (реєстрація в Міністерстві юстиції України від 23.07.2007 р. за № 846/14113) [Електронний ресурс]. - Режим доступу : http:// zakon5.rada.gov.ua/laws/show/z0846-07. - Назва з екрану.

12. Про диспансеризацію населення молодших спеціалістів з фрармацевтичною освітою у закладах охорони здоров'я : наказ МО3 України від 27.08.2010 р. за № 728 [Електронний ресурс]. - Режим доступу : http://zakon3. rada.gov.ua/laws/show/z1396-10. - Назва з екрану.

13. Примірне положення про центр первинної медичної (медико-санітарної) допомоги : наказ МОЗ України від 23.02.2012 р. № 131 [Електронний ресурс]. - Режим доступу : http://fp.com.ua/zakonodatelstvo/nakaz-moz-ukrayinivid-23-02-2012-131. - Назва з екрану.

14. Стратегія розвитку профілактики в охороні здоров'я в Україні / А. М. Сердюк, Ю. І. Кундієв, А. М. Нагорна, В. П. Широбоков // Журнал НАМН України. - 2012. - Т. 18, № 3. - С. 358-371.

15. Кондратюк Н. Ю. Нормативно-правові аспекти та управління процесом диспансеризації дорослого населення в Україні / Н. Ю. Кондратюк // Україна. Здоров'я нації. - 2014. - № 1. - С. 72-77.

16. Кондратюк Н. Ю. Щодо історії становлення та розвитку системи диспансеризації дорослого населення в Україні за часів СРСР (огляд літератури) / Н. Ю. Кондратюк // Україна. Здоров'я нації. - 2012. - № 4 (24). - С. $164-168$.

17. Лемішко Б. Б. Роль диспансеризації у комплексному механізмі державного управління станом здоров'я населення в закладі сімейної медицини [Електронний ресурс] / Б. Б. Лемішко // Демократичне врядування : науковий вісник Львівського регіонального інституту державного управління Національної академії державного управління при Президентові України. - Вип. 6. - Львів : ЛРІДУ НАДУ, 2010. - Режим доступу : http://lvivacademy. com/visnik6/index. html. - Назва з екрану.

18. Про схвалення Концепції розвитку системи громадського здоров'я : розпорядження Кабінету Міністрів України від 30 листопада 2016 р. № 1002-р [Електронний ресурс]. - Режим доступу : https://www.kmu.gov.ua/ua/npas/249618799. Назва з екрану. 
19. Співак М. В. Державна політика здоров'язбереження: світовий досвід і Україна : монографія / Інститут держави і права ім. В. М. Корецького НАН України. - К. : Логос, 2016. - 536 с.

20. Державна політика у сорері охорони здоров'я : кол. монографрія : у 2 ч. / [кол. авт. ; упоряд. Я. Ф. Радиш ; передм. та заг. ред. М. М. Білинської, Я. Ф. Радиша]. - К. : НАДУ, 2013. - Ч. 2. - 484 с.

\section{References}

1. Kurs na ozdorovleniye. Yevropeyskaya strategiya profilaktiki i borby s neinfektsyonnymi zabolevaniyami [European Strategy for the Prevention and Control of Noncommunicable Diseases]. (2012-2016). - Kopenhahen: ERB VOZ [in Russian].

2. (2012-2016). Plan deistviy po realizatsyi Yevropeyskoy strategii profilaktiki i borby s neinfektsyonnymi zabolevaniyami [Action plan for the implementation of the European Strategy for the Prevention and Control of Noncommunicable Diseases]. Kopenhahen: ERB VOZ [in Russian].

3. Sovremennye podkhody $\mathrm{k}$ profilaktike zabolevaniy $v$ mire [Modern approaches to the prevention of diseases in the world]. [Elektronnyy resurs]. - Retrieved from: http://meduniver.com/Medical/profilaktika/12.html. - Nazva z ekranu [in Russian].

4. Yevropeyskaya baza dannykh "Zdorovye dlya vsekh" [European database "Health for All"]. [Elektronnyy resurs]. Retrieved from: http://data.euro.who.int/hfadb/shell_ru.htm.I. - Nazva z ekranu [in Russian].

5. Konstytutsiia Ukrainy [Constitution of Ukraine]. [Elektronnyi resurs]. - Retrieved from: http://zakon0.rada.gov.ua/laws/ show/254\%D0\%BA/96-\%D0\%B2\%D1\%80. - Nazva z ekranu [in Ukrainian].

6. Osnovy zakonodavstva Ukrainy pro okhoronu zdorovia: zakon Ukrainy [Basic Laws of Ukraine on Health Care]. [Elektronnyi resurs]. - Retrieved from: http://zakon2.rada.gov.ua/laws/show/2801-12. - Nazva z ekranu [in Ukrainian].

7. Pro oboviazkovi medychni ohliady deiakykh katehorii naselennia: postanova KMU vid 5 serpnia 1994 roku № 532 [On obligatory medical examinations of certain categories of the population: the resolution of the Cabinet of Ministers of 5 August 1994 No. 532]. - Retrieved from: http://zakon3.rada.gov.ua/laws/show/532-94-\%D0\%BF?info=1. - Nazva z ekranu [in Ukrainian].

8. Pro Natsionalnu stratehiiu z ozdorovchoi rukhovoi aktyvnosti v Ukraini na period do 2025 roku: ukaz Prezydenta Ukrainy vid 9 liutoho 2016 roku № 42/2016 «Rukhova aktyvnist - zdorovyi sposib zhyttia - zdorova natsiia» [Pro Natsionalnu stratehiiu z ozdorovchoi rukhovoi aktivnosti v Ukraini na period do 2025 roku: ukaz Prezydenta Ukrainy vid 9 lutoho 2016 roku № 42/2016 “Rukhova aktyvnist - zdorovyi sposib zhyttia - zdorova natsiia”]. [On the National Strategy for Motor Rehabilitation in Ukraine up to 2025: Presidential Decree No. 42/2016 of February 9, 2016 «Motor activity - a healthy lifestyle - a healthy nation»]. [Elektronnyi resurs]. - Retrieved from: http://www.president.gov.ua/documents/422016-19772Nazva z ekranu [in Ukrainian].

9. Pro zatverdzhennia perelikiv zakladiv okhorony zdorovia, likarskykh, provizorskykh posad ta posad molodshykh spetsialistiv z farmatsevtychnoiu osvitoiu u zakladakh okhorony zdorovia: nakaz MOZ Ukrainy 28.10.2002 № 385 [On approval of lists of health care institutions, pharmacies, pharmacists and post positions of junior specialists with pharmaceutical education in health care institutions: the Order of the Ministry of Health of Ukraine dated October 28, 2002 No. 385]. Retrieved from: http://zakon3.rada.gov.ua/laws/show/z0892-02. - Nazva z ekranu [in Ukrainian].

10. Pro provedennia shchorichnoho profilaktychnoho medychnoho ohliadu derzhavnykh sluzhbovtsiv» (zi zminamy): nakaz MOZ Ukrainy, Holovnoho upravlinnia derzhavnoi sluzhby Ukrainy, Derzhavnoho upravlinnia spravamy vid 18.02.2003 № 75/24/1 [On conducting an annual preventive medical examination of civil servants "(as amended): Order of the Ministry of Health of Ukraine, the Main Department of the Civil Service of Ukraine, State Administration of Affairs of February 18, 2003 No. 75/24/1] (Zareiestrovano v Ministerstvi yustytsii Ukrainy 6 bereznia 2003 r. za № 184/7505). [in Ukrainian].

11. Pro zatverdzhennia Poriadku provedennia medychnykh ohliadiv pratsivnykiv pevnykh katehorii molodshykh spetsialistiv z farmatsevtychnoiu osvitoiu u zakladakh okhorony zdorovia: nakaz MOZ Ukrainy vid 21.05.2007r. za № 246 (reiestratsiia v Ministerstvi yustytsii Ukrainy vid 23.07.2007r. za №846/14113) [On Approval of the Procedure for conducting medical examinations of workers of certain categories of junior specialists with pharmaceutical education in health care institutions: the order of the Ministry of Health of Ukraine dated May 21, 2007. for the number 246 (registration with the Ministry of Justice of Ukraine dated July 23, 2007 No. 846/14113)]. - Retrieved from: http://zakon5.rada.gov.ua/laws/show/z0846-07. Nazva z ekranu [in Ukrainian].

12. Pro dyspanseryzatsiiu naselennia molodshykh spetsialistiv z farmatsevtychnoiu osvitoiu u zakladakh okhorony zdorovia: nakaz MOZ Ukrainy vid 27.08.2010 r. za № 728 [On medical examination of the population of junior specialists with pharmaceutical education in health care institutions: Order of the Ministry of Health of Ukraine dated August 27, 2010, No. 728]. - Retrieved from: http://zakon3.rada.gov.ua/laws/show/z1396-10. - Nazva z ekranu [in Ukrainian].

13. Prymirne polozhennia pro tsentr pervynnoi medychnoi (medyko-sanitarnoi) dopomohy: nakaz MOZ Ukrainy vid 23.02.2012 r. № 131 [Approximate provision for the center of primary medical (health-sanitary) assistance: Order of the Ministry of Health of Ukraine dated February 23, 2012 No. 131]. - Retrieved from: http://fp.com.ua/zakonodatelstvo/nakazmoz-ukrayini-vid-23-02-2012-131. - Nazva z ekranu [in Ukrainian].

14. Serdiuk, A. M., Kundiiev, lu. I., Nahorna, A.M., \& Shyrobokov, V.P. (2012). Stratehiia rozvytku profilaktyky v okhoroni zdorovia $\vee$ Ukraini [Strategy for the development of prevention in health care in Ukraine]. Zhurnal NAMN Ukrainy - Journal of NAMS of Ukraine, 18 (3), 358-371 [in Ukrainian].

15. Kondratiuk, N.Iu. (2014). Normatyvno-pravovi aspekty ta upravlinnia protsesom dyspanseryzatsii dorosloho naselennia $\checkmark$ Ukraini [Normative-legal aspects and management of the process of medical examination of adult population in Ukraine]. 
Ukraina. Zdorovia natsii - Ukraine. The Health of the Nation, 1, 72-77. - Retrieved from: http://nbuv.gov.ua/UJRN/ Uzn_2014_1_14. - Nazva z ekranu [in Ukrainian].

16. Kondratiuk, N.lu. (2012). Shchodo istorii stanovlennia ta rozvytku systemy dyspanseryzatsii dorosloho naselennia $v$ Ukraini za chasiv SRSR (ohliad literatury) [As to the history of the formation and development of the system of medical examination of the adult population in Ukraine during the USSR (review of literature)]. Ukraina. Zdorovia natsii - Ukraine. The Health of the Nation, 4 (24), 164-168 [in Ukrainian].

17. Lemishko, B.B. (2010). Rol dyspanseryzatsii u kompleksnomu mekhanizmi derzhavnoho upravlinnia stanom zdorovia naselennia $v$ zakladi simeinoi medytsyny [The role of medical examination in the complex mechanism of state administration of the state of health of the population in the institution of family medicine]. Demokratychne vriaduvannia: naukovyi visnyk Lvivskoho rehionalnoho instytutu derzhavnoho upravlinnia Natsionalnoi akademii derzhavnoho upravlinnia pry Prezydentovi Ukrainy [Democratic Governance: Scientific Bulletin of the Lviv Regional Institute of Public Administration of the National Academy of Public Administration under the President of Ukraine]. Lviv: LRIDU NADU. - Retrieved from: http://lvivacademy. com/visnik6/index.html. - Nazva z ekranu [in Ukrainian].

18. Pro skhvalennia Kontseptsii rozvytku systemy hromadskoho zdorovia: rozporiadzhennia Kabinetu Ministriv Ukrainy vid 30 lystopada 2016 r. № 1002-r [On Approval of the Concept of Development of the Public Health System: Order of the Cabinet of Ministers of Ukraine dated November 30, 2016 No. 1002-p]. - Retrieved from: https://www.kmu.gov.ua/ua/ npas/249618799. - Nazva z ekranu [in Ukrainian].

19. Spivak M.V. (2016). Derzhavna polityka zdorovia zberezhennia: svitovyi dosvid i Ukraina: monohrafiia [State policy of healthcare conservation: world experience and Ukraine: monograph]. In-t derzhavy i prava im. V.M. Koretskoho NAN Ukrainy. Kyiv: Lohos [in Ukrainian].

20. Radysh, Ia.F. (2013). Derzhavna polityka u sferi okhorony zdorovia: kol. monohr.: u 2 ch. [Public policy in health: call. monogr.: in 2 parts]. Kyiv: NADU [in Ukrainian].

\section{СОСТОЯНИЕ НОРМАТИВНО-ПРАВОВОГО РЕГУЛИРОВАНИЯ УПРАВЛЕНИЯ ПРОФИЛАКТИКОЙ НЕИНФЕКЦИОННЫХ ЗАБОЛЕВАНИЙ}

\section{В.А. Гандзюк}

Государственное научное учреждение «Научно-практический центр профилактической и клинической медицины» Государственного управления делами, г. Киев, Украина

Цель: определить направления совершенствования нормативно-правового обеспечения мер профилактики неинфекционных заболеваний у взрослого населения в условиях многопрофильного учреждения здравоохранения на основании обобщения и анализа действующих в системе здравоохранения Украины правовых актов.

Материалы и методы. Рассмотрены официальные нормативные документы по управлению профилактикой неинфекционных заболеваний. При проведении их анализа использованы контент-анализ, системный подход и анализ, библиографический и исторический методы.

Результаты. Улучшение профилактических мероприятий среди населения, исходя из общей десриниции «диспансеризация», предусматривает разработку и внедрение периодических профилактических осмотров среди взрослого населения по принципу их проведения в целевых группах, методологическим базисом для которых должны стать скрининговые программы раннего выявления наиболее распространенных неинфекционных заболеваний.

Выводы. При проведении контент-анализа нормативно-правовой базы по управлению профилактикой в Украине установлено, что среди действующих приказов МЗ Украины отсутствуют четкие критерии, отражающие степень соблюдения организационных принципов оказания профилактической помощи, как следствие этого оценка качества профилактической помощи и ее эффрективности не проводится, а современные управленческие технологии не используются.

КЛЮЧЕВЫЕ СЛОВА: диспансеризация; профилактические осмотры; скрининговые программы; управление профилактикой; неинфекционные заболевания.

\section{STATUS OF NORMATIVE-LEGAL REGULATION OF CONTROL OF PREVENTION OF NON-COMMUNI- CABLE DISEASES}

V.A. Gandziuk

State Institution of Science «Research and Practical Centre of Preventive and Clinical Medicine» State Administration Department, Kyiv, Ukraine

Purpose: to identify the areas for improving the regulatory and legal support normative-legal regulation for NCD prevention measures in the adult population in the context of a multidisciplinary health care institution on the basis of generalization and analysis of legal acts in the health care system of Ukraine. 
Materials and Methods. The official normative documents on the management of the prevention of noncommunicable diseases were considered. On the analysis of their use of content analysis, a systematic approach and analysis, bibliographic and historical methods.

Results. Improvement of preventive measures among the population, based on the general definition of "medical examination", provides for the development and implementation of periodic preventive examinations among adults according to the principle of their conduct in target groups, the methodological basis for which should be screening programs for early detection of the most common NCD.

Conclusions. When carrying out the content analysis of the legal framework on prevention management in Ukraine, it is established that among the current orders of the Ministry of Health of Ukraine there are no clear criteria reflecting the degree of adherence to the organizational principles for the provision of preventive care, as a result, the quality of preventive care and its effectiveness is not assessed, and modern management technologies are not used.

\footnotetext{
KEY WORDS: clinical examination; preventive examinations; screening programs; prevention management; NCD.
}

Рукопис надійшов до редакції 08.11.2017 p.

\section{Відомості про автора:}

Гандзюк Володимир Андрійович - кандидат медичних наук, старший науковий співробітник наукового відділу організації медичної допомоги Державної наукової установи «Науково-практичний центр просрілактичної та клінічної медицини» Державного управління справами, м. Київ; тел.: +38(067) 445-69-09. 